\title{
COMPARISON OF LEARNING ENVIRONMENT IN 3 DIFFERENT SETTINGS TO SUPPORT CLINICAL SKILLS ACQUISITION IN UNDERGRADUATE MEDICAL STUDENTS
}

\author{
Kirubashni Mohan, Ova Emilia, Widyandana \\ Fakultas Kedokteran Universitas Gadjah Mada, Yogyakarta
}

\begin{abstract}
ABSTRAK
Latar Belakang: Integrasi antara pendidikan pre-klinik, laboratorium keterampilan medik dan seting klinik riil sangat direkomendasikan. Penelitian ini akan mengidentifikasi seting klinik yang sesuai dengan pendidikan S1 kedokteran. Penelitian ini bertujuan untuk membandingkan 3 (tiga) seting klinik yang berbeda (Rumab Sakit Sardjito, Rumab Sakit Klaten, dan Puskesmas), untuk mengetabui seting klinik yang paling sesuai untuk pendidikan keterampilan klinik di pendidikan S1 kedokteran.

Metode: Merupakan penelitian deskriptif kuantitatif, menggunakan metode cross sectional. Pengumpulan data menggunakan kuesioner yang diisi oleh mabasiswa yang sedang menjalani pendidikan profesi kedokteran di Rumab Sakit Sardjito, Rumab Sakit Klaten dan Puskesmas. Analisis data menggunakan uji ANNOVA.

Hasil: Puskesmas menunjukkan skor rata-rata tertinggi dibandingkan dengan Rumab Sakit Sardjito dan Klaten dalam aspek lingkungan pembelajaran secara umum, otonomi, dukungan sosial dan kejelasan peran. Rumah Sakit Sardjito unggul dalam aspek supervisi, beban kerja, penekanan pada proses belajar mengajar dan variasi kasus. Didapatkan korelasi positif antara lingkungan pembelajaran dan kesempatan untuk berlatih keterampilan.

Kesimpulan: Puskesmas sebagai pusat pelayanan kesehatan primer memiliki lingkungan pembelajaran klinik yang lebib baik jika dibandingkan dengan Rumab Sakit Sardjito dan Rumab Sakit Klaten, tetapi memiliki skor rata-rata yang rendab di domain penekanan proses belajar mengajar dan variasi kasus. Didapatkan korelasi yang positif antara lingkungan pembelajaran dan kesempatan untuk berlatib keterampilan. Tidak ditemukan adanya korelasi antara kesempatan berlatib keterampilan dan gender.
\end{abstract}

Kata kunci: lingkungan pembelajaran klinik, latiban keterampilan, pendidikan S1, kesempatan berlatib keterampilan

\begin{abstract}
Background: Integration between preclinical basic science education, skills training program in the laboratory setting and real clinical setting is recommended. This study explores clinical setting which suitable for undergraduate skills training program. The purpose of this study is to compare 3 different clinical settings (Sardjito Hospital, Klaten Hospital, and Puskesmas), which is appropriate for undergraduate clinical skills training.

Method: This was a descriptive quantitative study, using cross sectional method. Data collection used self administrated questionnaire comprised of clerkship students who pooled of Sardjito Hospital, Klaten Hospital and Puskesmas (Primary Health Centre). Data analysis was done using ANNOVA test.

Results: The Puskesmas scored the highest mean compared to Sardjito Hospital and Klaten Hospital for an overall learning environment and also in the scales for autonomy, social support, and role clarity. Sardjito Hospital scored the highest mean for the scales of supervision, workload, emphasis on teaching and learning and variety. There is a positive correlation between the learning environment and skills practice opportunity.

Conclusion: Puskesmas as primary health centers is a better overall clinical learning environment compared to Sardjito Hospital and Klaten Hospital, but scored low means in domains such as emphasis on teaching and learning and variety. There is a positive correlation between the learning environments and skills practice opportunity with different features for each setting. There is no correlation between skills practice opportunity and gender or marital status.
\end{abstract}

Keywords: clinical learning environment, skills training, undergraduate, skills practice opportunity

Korespondensi: kiru.isis@yahoo.com; kiru-isis@hotmail.com 


\section{INTRODUCTION}

The Global Minimum Essential Requirements is a set of minimum competencies for a medical doctor developed by The Institute for International Medical Education (IIME). This concept has inspired the development of the Indonesian National Standard of Competency for Medical Education. Following the government's decision to implement the Competence Based Curriculum (CBC) in medical education throughout the country, all Faculties of Medicine in Indonesia started to develop their curriculum based on that national standard including the Faculty of Medicine Universitas Gadjah Mada (FM GMU). ${ }^{1}$

The FM of GMU has been developing skills training programmes since 1992. In the skills lab, students practice their skills until they are competent enough based on a skills training curriculum that matches the competencybased curriculum that is being developed. Students need time and effort to master a skill and to reach the highest level of clinical competence possible based on the CBC, in addition to the system that already exists. ${ }^{2}$

After finishing pre clinical level, students entering clinical rotation in the real clinical environment. There is a problems during this transition period. ${ }^{3}$ Students encounter problems when they have to implement their clinical skills taught in skills lab to the real patients. ${ }^{4}$

Realizing those problems above, innovation should be taken to modify the pre-clinical skills training in the laboratory. Collaboration between skills laboratory and real clinical environments for undergraduate students practice was recommended by Dornan et al. ${ }^{5}$ Early clinical experiences have many advantages to prepare students entering clerkship, it give pictures to the students about clinical realities, improve clinical reasoning abilities, learn how to collaborate with other health workers, etc.

Therefore, preparation of suitable clinical environments will be needed for the students to practice their skills, such as; Puskesmas, District Hospital, or Teaching Hospital.

\section{METHOD}

This is a descriptive quantitative study, using a cross sectional methods. Data collection using survey questionnaires to 76 clerkship students in Faculty of Medicine, Universitas Gadjah Mada. The instrument already validated by Emilia (2003) in the context of clinical rotation. It contains of 28 items, which is divided into 7 domains. The seven domains were "autonomy" (4 items), "supervision" (4 items), "social support" (5 items), "workload" (4 items), "role clarity" (3 items), "emphasis on teaching and learning" (5 items), and "variety" (3 items). ${ }^{6}$

Survey conducted by approaching students in their clinical rotation in three clinical environments; Puskesmas as primary care, Klaten Hospital as secondary care, and Department Internal Medicine, Sardjito Hospital as tertiary care/ teaching hospital. Clerkship students were voluntary asked to fill out the questionnaires and get small reward from the research team.

The data was analyzed using One Way ANOVA for each subscale of the questionnaire using SPSS 16.0.

\section{RESULTS AND DISCUSSION}

A total number of 76 respondents in the department of internal medicine in Sardjito Hospital, Klaten Hospital, and 11 Puskesmas were recruited for this study. Data was analyzed based on their gender, marital status and learning environment, namely Sardjito Hospital, Klaten Hospital and Puskesmas, and opportunity to practice skills. All of the respondents were between ages of 22 to 29 years old, with the majority of the respondents are of $23(38.4 \%)$ and 24 (46.6\%) years of age, followed by $6.4 \%$ being 25 years of age. There were 41 female respondents and 35 were male. Six respondents were married, the rest were single.

In general, Puskesmas was a better clinical learning environment compared to Sardjito Hospital and Klaten Hospital for undergraduate students practicing their clinical skills. However, Puskesmas scored low in domains of teaching and learning and variety. Puskesmas was better than the other two environments in the scales for autonomy, social support, and role clarity. Sardjito Hospital was the best clinical learning environment for the scales of supervision, workload, emphasis on teaching and learning and variety. A very good score was obtained especially for emphasis on teaching and learning, see Table 1. 
Table 1. ANNOVA test results comparing learning environment scores between 3 clinical settings

\begin{tabular}{|c|c|c|c|c|c|c|c|c|c|}
\hline \multirow{2}{*}{$\begin{array}{c}\text { Scales/ } \\
\text { Environment }\end{array}$} & \multicolumn{2}{|c|}{ Sardjito Hospital } & \multicolumn{2}{|c|}{ Klaten Hospital } & \multicolumn{2}{|c|}{ Puskesmas } & \multirow[b]{2}{*}{$F$} & \multirow[b]{2}{*}{$\mathrm{p}$} & \multirow[b]{2}{*}{ Total } \\
\hline & Mean & SD & Mean & SD & Mean & SD & & & \\
\hline $\begin{array}{l}\text { Learning } \\
\text { Environment }\end{array}$ & 12.96 & 2.05 & 12.36 & 1.72 & 13.01 & 1.57 & 10.44 & 0.00 & 12.78 \\
\hline $\mathrm{AU}$ & 11.44 & 2.90 & 12.25 & 2.43 & 14.25 & 2.24 & 38.24 & 0.00 & 12.65 \\
\hline SU & 12.44 & 2.90 & 11.60 & 2.56 & 12.41 & 2.40 & 7.51 & 0.00 & 12.15 \\
\hline SS & 15.53 & 3.56 & 14.78 & 2.74 & 16.71 & 2.54 & 16.26 & 0.00 & 15.67 \\
\hline WL & 12.88 & 2.46 & 11.85 & 2.33 & 12.26 & 1.93 & 3.85 & 0.03 & 12.33 \\
\hline $\mathrm{RC}$ & 9.49 & 2.10 & 9.55 & 1.66 & 10.49 & 1.66 & 10.54 & 0.00 & 9.84 \\
\hline ETL & 18.85 & 3.21 & 17.40 & 2.95 & 15.07 & 3.30 & 23.5 & 0.00 & 17.01 \\
\hline $\mathrm{VA}$ & 10.07 & 2.27 & 9.07 & 1.73 & 9.26 & 1.83 & 3.48 & 0.04 & 9.47 \\
\hline
\end{tabular}

There are differences in the mean scores of the learning environment between Dr Sardjito Hospital, Klaten Hospital and Puskesmas. Puskesmas has the highest mean score of (13.01), followed by Sardjito Hospital (12.96) and Klaten Hospital (12.36). This shows that students perceive that primary health care is the most conducive environment for learning. Training in rural settings stimulates greater competence, confidence and organizational skills in nursing students compared to training in metropolitan settings. ${ }^{?}$

In the first domain, autonomy, the highest mean was scored by the Puskesmas (14.25), followed by Klaten Hospital (12.25) and Sardjito Hospital (11.44). In the Puskesmas, very often, there is only one senior doctor or resident in charge of the facility. Hence this provides an opportunity for students doing their clinical rotation to be more involved in the health care service. Sardjito Hospital and Klaten Hospital are teaching hospitals and referral hospitals, they have much more staff and students, meaning that students's opportunity to practice their skills has to be shared. Research suggests that when educators are more supportive of student autonomy, students not only display a more humanistic orientation toward patients but also show greater conceptual understanding and better psychological adjustment.

In the second domain, supervision, Sardjito Hospital and Puskesmas scored almost the same means, 12.44 and 12.41 respectively. Klaten Hospital scored a slightly lower mean. Sardjito Hospital is the main teaching hospital, hence it is expected that the students receive appropriate guidance and support from the staff and residents in learning and practice activities. Kilminster and Jolly ${ }^{8}$ defined supervision as the provision of monitoring, guidance and feedback on matters of personal, professional and educational development in the context of the doctor's care of patients. The less busy working atmosphere of the Puskesmas may also give the staff and residents at this faculty more time and patience to provide the guidance, attention and feedback needed by the students. This is important as according to students' perceptions, providing observation and constructive feedback are key features of effective clinical learning experiences. ${ }^{9}$ Although Klaten Hospital is also a teaching hospital, guiding and teaching may not be as much of a priority as in Sardjito Hospital.

The Puskesmas scored the highest mean for social support (16.71), followed by Sardjito Hospital (15.53) and Klaten Hospital (14.78). At the Puskesmas, the undergraduate medical students feel accepted, recognized and valued as members of the team by hospital staff and peers probably because they are given a higher level of responsibility and are trusted with more tasks as discussed earlier.

For the domain workload, the means are almost the same between Sardjito Hospital, Klaten Hospital and Puskesmas at 12.88, 11.85 and 12.26. Sardjito Hospital probably scored the highest because as discussed earlier, there are many undergraduate medical students, residents 
and trainee nurses who can share the workload, hence the task requirements in the rotation enables a reasonable balance between clinical activities and learning.

For role clarity, the means for the three settings are 10.49, 9.55 and 9.49, with the Puskesmas scoring the highest and Sardjito Hospital scoring the lowest mean. Being more independent at the Puskesmas may have contributed to the students perception of having better role clarity, as they can feel what it is like to be a health care provider at a basic and community level.

Sardjito Hospital scored the highest mean for emphasis on teaching and learning (18.85), followed by Klaten Hospital and Puskesmas at 17.40 and 15.70 respectively. The first two hospitals mentioned are teaching hospitals; this may explain why the teaching staff at the departments facilitate application of knowledge and skills practice better than at the Puskesmas. To further support this opinion, Hofman and Donaldson ${ }^{10}$ described three major contextual tensions that affect teaching and learning in the clinical environment: 1) patient census, that is the number of patients, the types of illnesses, and the pace at which patients move through the healthcare system; 2) the pace at which ongoing patient care activities are taking place; and 3) the multiple and conflicting responsibilities of the team, that is, the challenge of appropriately allocating time to teaching, learning, patient care and other commitments.

In the variety domain, Sardjito Hospital scored the highest mean at 10.07 . Since this hospital is a main teaching hospital as well as the top referral hospital, it is expected that there is diversity and variety in learning experience. Although the Puskesmas scored the highest mean for the overall learning environment, it is weak especially in the domains of emphasis on teaching and learning and variety. Sardjito Hospital scored the highest means in 4 domains compared to only 3 domains for Puskesmas. Sardjito Hospital has the potential as a good learning environment especially because it scored very well compared to the others in the domain of emphasis on teaching and learning. It is also a good environment as it shows to have variety in its learning experience.

Looking at the opportunity to practice, Klaten Hospital scored the highest mean for skills practice opportunity at 38.03 with $\mathrm{SD} \pm 2.27$ followed by Sardjito Hospital (mean $=37.99, \mathrm{SD} \pm 2.90)$, and Puskesmas (mean= 36.96, $\mathrm{SD} \pm 2.75)$. The $\mathrm{F}$ and $\mathrm{p}$ values were 7.41 and 0.00 respectively (Table 2 ). Primary health care was good in providing opportunity for learning examination and emergency cases, while in district hospital students learnt more interpersonal communication, examination and injection/IV line insertion. In tertiary hospital, in fact, students learnt more anamnesis, basic physical examination, vital signs measurement, aseptic technique and ECG examination.

There is no relationship between skills practice opportunity and gender. Both male and female students had similar opportunities in the three clinical settings. At least $87.8 \%$ of students reported for having 'enough' practice opportunities in Sardjito Hospital. This number is even higher in Klaten Hospital and the Puskesmas (97.3\%). Marital status showed no relationship with the skills practice opportunity. 
Table 2. ANNOVA test results comparing means of skills practice opportunity by skills between 3 clinical settings

\begin{tabular}{|c|c|c|c|c|c|c|c|c|c|}
\hline \multirow{2}{*}{$\begin{array}{l}\text { Learning } \\
\text { Environment/ } \\
\text { Skills }\end{array}$} & \multicolumn{2}{|c|}{ Sardjito Hospital } & \multicolumn{2}{|c|}{ Klaten Hospital } & \multicolumn{2}{|c|}{ Puskesmas } & \multirow{2}{*}{$\mathrm{F}$} & \multirow{2}{*}{$\mathrm{p}$} & \multirow{2}{*}{ Total } \\
\hline & Mean & SD & Mean & SD & Mean & SD & & & \\
\hline $\begin{array}{l}\text { Interpersonal } \\
\text { Communication }\end{array}$ & 3.89 & 0.46 & 3.90 & 0.30 & 3.88 & 0.41 & 0.21 & 0.82 & 3.89 \\
\hline $\begin{array}{l}\text { Basic Physical } \\
\text { Examination }\end{array}$ & 3.95 & 0.28 & 3.92 & 0.36 & 3.93 & 0.35 & 1.63 & 0.85 & 3.93 \\
\hline $\begin{array}{l}\text { Vital Signs } \\
\text { Measurement }\end{array}$ & 3.95 & 0.28 & 3.89 & 0.39 & 3.90 & 0.38 & 1.07 & 0.35 & 3.91 \\
\hline Aseptic Technique & 3.75 & 0.57 & 3.74 & 0.50 & 3.66 & 0.61 & 0.77 & 0.47 & 3.72 \\
\hline $\begin{array}{l}\text { Intravenous Infusion/ } \\
\text { Injection }\end{array}$ & 3.49 & 0.80 & 3.70 & 0.59 & 3.53 & 0.67 & 5.28 & 0.01 & 3.57 \\
\hline $\begin{array}{l}\text { Abdominal } \\
\text { Examination }\end{array}$ & 3.85 & 0.43 & 3.75 & 0.52 & 3.86 & 0.38 & 1.86 & 1.16 & 3.82 \\
\hline Thorax Examination & 3.90 & 0.41 & 3.92 & 0.27 & 3.82 & 0.45 & 2.20 & 0.12 & 3.88 \\
\hline Trauma/ Emergency & 3.51 & 0.78 & 3.49 & 0.59 & 3.92 & 0.63 & 2.45 & 0.09 & 3.64 \\
\hline Anamnesis & 3.92 & 0.28 & 3.88 & 0.33 & 3.75 & 0.47 & 3.94 & 0.02 & 3.85 \\
\hline $\begin{array}{l}\text { ECG } \\
\text { Examination }\end{array}$ & 3.78 & 0.71 & 3.71 & 0.57 & 3.12 & 1.12 & 4.74 & 0.00 & 3.54 \\
\hline
\end{tabular}

For skills practice opportunity, Klaten Hospital scored the highest means (38.03) followed by Sardjito Hospital (37.99) and Puskesmas (36.96). The p value is less than 0.05. It is unclear why skills practice opportunities are better in Klaten Hospital. However, as discussed earlier, the students also have a very good chance to perform their skills independently at the Puskesmas. Improving the learning environment in Sardjito Hospital and Puskesmas will increase the skills practice opportunity in those settings as there is a positive correlation between the two variables.

A chi-square analysis was used to find a relationship between gender and skills practice opportunity. The results obtained were not significant differences of skills practice opportunity in Sardjito Hospital, Klaten Hospital and Puskesmas, among male and female students. However, based on the frequencies of males and females who reported to having 'not enough' and 'enough' practice opportunities, a few things can be discussed. A total of $87.8 \%$ of students reported to having 'enough' practice opportunities in Sardjito Hospital. In Klaten Hospital and the Puskesmas this value was 97.3\%. For Sardjito Hospital, $18.8 \%$ of the males did not have enough opportunities while the figure for females was $12.2 \%$. In
Klaten Hospital, 6.3\%of the males reported their skills practice opportunities as 'not enough' while all the females had 'enough' opportunities. For the Puskesmas, $3.1 \%$ of the males and $2.4 \%$ of females did not have enough opportunities. From these figures, it is shown that the females seem to have better opportunities to perform skills in the clinical setting. A longitudinal study that examined students on their first clinical firms showed that men and women have significant differences when interacting with the learning environment. ${ }^{11}$ In both, a perception that bad events in the learning environment were persistent and pervasive appeared to be causal of high achievement in tests of knowledge. In men this was dominantly mediated through fear of negative evaluation and anxiety. In women the path appeared to be direct and associated with a sense of reduced self efficacy. The difference in these values could also be related to the initiative, interest, diligence and responsibility of the individual students themselves.

The skills practice opportunity showed differences among married and unmarried students. But the number was too small to be analysed further. A total of $84.9 \%$ of the students had 'enough' opportunities while 97.3\% of the students in both Klaten Hospital and Puskesmas had 
'enough' opportunities. Single student had higher (88\%) chances for having enough practice opportunities compared to married students (50\%).Many factors could possibly cause this differences such as difficult to manage time, difficult to get along with other students, or perhaps family problems.

\section{CONCLUSION}

Puskesmas is a better clinical learning environment compared to Sardjito Hospital and Klaten Hospital for undergraduate students practicing their clinical skills. This study showed that each clinical setting have its own positive features. The learning environments showed relationship with skills practice opportunity. Skills practice opportunity was not related with gender or marital status of students.

\section{SUGGESTIONS}

Further studies with more samples should be undertaken to explore more detail for each clinical learning environment. More qualitative data from the students should be obtained to explore the clinical learning environments. Students should be prepared before learning indifferent clinical setting, as they will encounter different challenges during the rotation.

\section{REFERENCES}

1. Savitri T. Perumusan kompetensi dokter di Indonesia. Jurnal Pendidikan Kedokteran dan Profesi Kesehatan Indonesia. 2005;1:11-7.

2. Patrick J. Training: research and practice. London: Academic Press; 1992.
3. Prince KJAH, Scherpbier AJJA, van der Vleuten CPM, Boshuizen HPA. Students opinions about their preparation for clinical practice. Med Ed. 2005;39:704-12.

4. Smith B. From simulation to reality-breaking down the barriers. The Clin Teach. 2006;3(2): 112-7.

5. Dornan T, Littlewood S, Margolis SA, Scherpbier A, Spencer J, Ypinazar V. How can experience in clinical and community settings contribute to early medical education? A BEME systematic review. Med Teach. 2006;28:3-18.

6. Emilia $\mathrm{O}$. The relationship between the clinical learning environment and the approaches to learning of medical students [dissertation]. Sidney: University of New South Wales; 2003.

7. Edward H, Smith S, Courtney M, Finlayson K, Chapman H. The impact of clinical learning placement location on nursing students competence $\&$ preparedness for practice. Nurse Education Today. 2004;24(4):248-55.

8. Kilminster SM, Jolly BC. Effective supervision in clinical practice settings: a literature review. Med Ed. 2000;34:827-40.

9. Van der Hem-Stokroos HH, Daelmans HEM, van der Vleuten CPM, Haarman HJThM, Scherpbier AJJA. A qualitative study of constructive clinical learning experiences. Med Teach. 2003;25:120-6.

10. Hofman KG, Donaldson JE. Contextual tensions of the clinical environment and their influence on teaching and learning. Med Ed. 2004; 38:448-54.

11. de Saintonge DMC, Dunn DM. Gender and achievement in clinical medical students: a path analysis. Med Ed. 2001;35(11):1024-33. 